\title{
Perfil da infecção pelo vírus da diarreia viral bovina (BVDV) em um rebanho bovino leiteiro de alta produção e com programa de vacinação contra o BVDV ${ }^{1}$
}

\author{
Stelamaris Dezen ${ }^{2}$, Rodrigo A.A. Otonel ${ }^{4}$, Alice F. Alfieri ${ }^{4}$, Michele Lunardi ${ }^{3}$ \\ e Amauri A. Alfieri* ${ }^{4 *}$
}

\begin{abstract}
Dezen S., Otonel R.A.A., Alfieri A.F., Lunardi M. \& Alfieri A.A. 2013. [Bovine viral diarrhea virus (BVDV) infection profile in a high production dairy herd with vaccination program against BVDV.] Perfil da infecção pelo vírus da diarreia viral bovina (BVDV) em um rebanho bovino leiteiro de alta produção e com programa de vacinação contra o BVDV. Pesquisa Veterinária Brasileira 33(2):141-147. Laboratório de Virologia Animal, Departamento de Medicina Veterinária Preventiva, Centro de Ciências Agrárias, Universidade Estadual de Londrina, Cx. Postal 6001, Londrina, PR 86051-990, Brazil. E-mail: alfieri@uel.br

The profile of bovine viral diarrhea virus (BVDV) infection was studies in a high production dairy herd selected based on a history of reproductive failures and regular vaccination against BVDV. Virus identification was performed by RT-PCR and serological profile was determined by virus-neutralization (VN). Initially, 100\% $(n=692)$ of the animals in the herd were monitored for identification of an active infection by RT-PCR in sera. Four months later, all positive animals $(n=29)$ were retested by RT-PCR, along with newly born animals $(n=72)$, or those that had reproductive failures $(n=36)$ in the interval. The RT-PCR assay identified 27 transiently infected animals and three persistently infected (PI). Serology performed only in positive animals in the first RT-PCR and in cows with reproductive failures between the first and second RT-PCR analysis, showed large variation VN antibody titers and seroconversion in most animals. Increases in VN titers were demonstrated, with variation between 3 and $8 \log _{2}$, indicating virus circulation within the herd. Virus circulation in the vaccinated herd evaluated in this study was likely responsible for reproductive failures observed in cows with low VN titers and for fetal infections. These results demonstrate that control of BVDV infection by regular vaccination in dairy cattle herds with PI animals represents a great challenge for the prophylaxis of this infection.
\end{abstract}

INDEX TERMS: Diagnosis, bovine viral diarrhea virus, BVDV, persistent infection, RT-PCR, virus-neutralization, vaccine.

RESUMO.- A infecção pelo vírus da diarreia viral bovina (BVDV) foi avaliada em um rebanho bovino leiteiro de alta produção com histórico de problemas reprodutivos e de vacinação regular contra o BVDV. A identificação do vírus foi

\footnotetext{
${ }^{1}$ Recebido em 20 de março de 2012.

Aceito para publicação em 7 de maio de 2012.

${ }^{2}$ Laboratório der Biologia Molecular, Instituto Federal Catarinense, Cx. Postal 21, Araquari, SC 89245-000, Brasil.

${ }^{3}$ Laboratório de Microbiologia Veterinária, Hospital Veterinário, Universidade de Cuiabá, Av. Beira Rio 3100, Cuiabá, MT 78065-900, Brasil.

${ }^{4}$ Laboratório de Virologia Animal, Departamento de Medicina Veterinária Preventiva, Centro de Ciências Agrárias, Universidade Estadual de Londrina (UEL), Cx. Postal 6001, Londrina, PR 86051-990, Brasil. *Autor para correspondência: alfieri@uel.br
}

realizada por RT-PCR em soro sanguíneo e o perfil sorológico por vírus-neutralização. Inicialmente, 100\% ( $n=692)$ dos animais do rebanho foram avaliados com relação à presença de infecção ativa pelo BVDV por meio da RT-PCR. Quatro meses após, todos os animais positivos $(n=29)$ na primeira avaliação foram avaliados novamente pela RT-PCR, assim como todos os animais que nasceram $(n=72)$ e os que apresentaram problemas reprodutivos $(n=36)$ no intervalo entre a primeira e a segunda colheita de sangue. Os resultados finais do estudo possibilitaram identificar 27 animais transitoriamente infectados e três animais persistentemente infectados (PI). A sorologia, realizada apenas nos animais positivos na primeira avaliação pela RT-PCR e nas vacas que apresentaram problemas reprodutivos entre 
a primeira e a segunda RT-PCR, demonstrou grande flutuação nos títulos de anticorpos neutralizantes, além de soroconversão na maioria dos animais. Foram identificados aumentos nos títulos de anticorpos neutralizantes que variaram entre 3 e $8 \log _{2}$, indicando infecção ativa no rebanho. A circulação viral no rebanho avaliado foi responsável pela expressão de sinais clínicos da esfera reprodutiva em animais com baixo título de anticorpos e consequente falha na proteção fetal. Os resultados demonstram que o controle da infecção pelo BVDV apenas por meio da vacinação regular em rebanhos com animais PI pode não ser eficaz na profilaxia dessa virose.

TERMOS DE INDEXAÇ̃̃: Diagnóstico, vírus da diarreia viral bovina, BVDV, infecção persistente, RT-PCR, vírus-neutralização, vacina.

\section{INTRODUÇ̃̃O}

O vírus da diarreia viral bovina (Bovine viral diarrhea virus - BVDV) é considerado, em todo o mundo, um dos mais importantes patógenos para os rebanhos bovinos (Ridpath \& Flores 2007). O BVDV é classificado na família Flaviviridae, gênero Pestivirus, juntamente com o vírus da peste suína clássica (Classical swine fever virus - CSFV) e o vírus da doença da fronteira dos ovinos (Border disease virus - BDV) (Baker 1995).

A infecção pelo BVDV tem sido associada com uma grande variedade de manifestações clínicas que incluem desde infecções inaparentes até enfermidades fatais como a Doença das Mucosas (DM). Entre as consequências mais frequentes da infecção pelo BVDV destacam-se: enfermidade gastroentérica e/ou respiratória, doença hemorrágica, perdas reprodutivas devido à infertilidade temporária, mortalidades embrionária e fetal, além de mumificação fetal, malformação, natimortalidade e o nascimento de bezerros fracos e/ou com peso corporal abaixo da média da raça (Flores et al. 2000, Brock et al. 2005, Lunardi et al. 2008).

De acordo com a característica biológica de produzir ou não efeito citopatogênico em cultivo celular, os isolados de campo do BVDV podem ser classificados em biotipo citopático (CP) e biotipo não-citopático (NCP). A infecção em fêmeas gestantes entre os dias 40 e 120 de gestação com cepas virais NCP é, frequentemente, seguida de infecção fetal com indução de imunotolerância. Fetos infectados nesse período nascem imunotolerantes e persistentemente infectados (PI) com o BVDV (Brock et al. 2005). A prevalência de animais PI em rebanhos bovinos infectados pode variar de $0,5 \%$ a $2 \%$ e, em bovinos jovens, pode ser até o dobro (Houe 1999). Os animais PI constituem o principal fator de risco da infecção por serem os responsáveis pela disseminação e perpetuação do BVDV nos rebanhos bovinos (Bolin \& Grooms 2004) dificultando o controle e profilaxia da infecção (Kennedy 2006).

Os isolados de campo circulantes do BVDV são classificados em duas espécies, BVDV 1 e BVDV 2. Com base na sequência de nucleotídeos, o BVDV 1 pode ainda ser subdividido em 16 subgenotipos (BVDV 1a - BVDV 1p) e o BVDV 2 em dois subgenotipos (BVDV 2a e BVDV 2b) (Flores et al. 2002, Kadir et al. 2008, Nagai et al. 2008). No Brasil, a infecção pelo BVDV está amplamente disseminada tanto nos rebanhos bovinos de leite, quanto nos de corte (Quincozes et al. 2007) onde os isolados virais foram caracterizados geneticamente e identificados como pertencentes às espécies BVDV 1 e 2 (Flores et al. 2005, Cortez e al. 2006, Lunardi et al. 2008). Entretanto pestivírus atípicos tem sido descritos no mundo como o Giraffe isolado de girafano Kenya (Becher et al. 2003), Pronghorn virus isolado de antílope nos EUA (Vilcek et al. 2005), Bungowannah virus isolado em suíno na Austrália (Kirkland et al. 2007) e o Hobi-like virus, identificado em várias partes do mundo e também no Brasil (Schirrmier et al. 2004, Cortez et al. 2006).

A grande variabilidade antigênica entre os isolados do BVDV representa um obstáculo para a obtenção de proteção cruzada contra o amplo espectro antigênico dos isolados. 0 surgimento de cepas antigenicamente distintas e altamente virulentas do BVDV reascendeu a discussão sobre a eficácia das vacinas comerciais disponíveis (Fulton \& Burge 2000).

Assim, o estudo teve o objetivo de avaliar o perfil da infecção pelo BVDV em um rebanho bovino leiteiro de alta produção que, mesmo com manejos nutricional, zootécnico e sanitário adequados, apresentava baixa eficiência reprodutiva caracterizada por alta taxa de mortalidade embrionária e o consequente aumento no intervalo entre partos.

\section{MATERIAL E MÉTODOS}

Animais. 0 rebanho avaliado, com predominância para a raça Holandês Preto e Branco e uma pequena percentagem de animais da raça Girolando, proveniente da região oeste do estado do Pa-

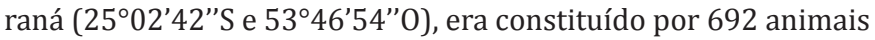
sendo, 27 bezerras lactentes ( 0 a 2 meses), 43 bezerras desmamadas ( 2 a 8 meses), 235 novilhas (acima de 8 meses), 331 vacas em lactação, 54 vacas secas e 2 touros. Os animais do plantel estavam distribuídos em 5 categorias distintas que eram criadas, separadamente, em diferentes unidades da propriedade. A produção leiteira demonstrava variações de acordo com a sazonalidade oscilando entre 9115 a $9785 \mathrm{~kg} /$ dia, com média aproximada de 27,5 a 29,5 kg/dia/vaca em lactação.

Os manejos de ordenha, reprodução, sanidade e nutrição adotados eram adequados a um rebanho bovino leiteiro de alto nível zootécnico. Nos últimos cinco anos, todos os animais em fase de reprodução eram regularmente vacinados, a cada seis meses, com vacinas inativadas, contra o BVDV, além de outras doenças como a Rinotraqueíte Infecciosa Bovina (IBR) e a Leptospirose. Devido à produção leiteira intensiva e à consequente alta taxa de reposição, havia a necessidade de, em algumas situações, adquirir novilhas e/ou vacas lactantes de outros plantéis, caracterizando dessa forma o rebanho como aberto. Mesmo utilizando biotécnicas da reprodução (inseminação artificial/transferência de embriões) e manejo sanitário adequado, direcionado para as principais doenças da reprodução, os resultados das taxas utilizadas para avaliar a eficiência reprodutiva do plantel eram inferiores aos adequados, particularmente aqueles relacionados às taxas de concepção e de mortalidade embrionária (precoce e tardia). Considerando tanto a produção quanto o manejo intensivo, aos quais os animais eram submetidos, os abortamentos, apesar de ocorrerem, eram esporádicos e em percentual não preocupante. Os dados reprodutivos mostraram um rebanho com período médio entre inseminações de 35 dias; retorno ao cio regular; período médio de cobertura pós-parto de 72 dias; intervalo entre partos de 16,6 meses; número de serviços/prenhez de 3,6; taxa de concepção de 29,3\%; taxa de prenhez de $10,9 \%$ e $72,3 \%$ de taxa de cios observados 
com mais de 60 dias pós-parto. Durante o período do estudo (18 meses) não houve relatos de malformações e mumificações fetais, natimortalidade ou o nascimento de animais fracos ou com peso corporal abaixo da média da raça.

Soro dos animais. 0 sangue foi obtido por meio da punção, com agulhas descartáveis, da veia caudal ou da veia jugular de $100 \%(n=692)$ dos animais do rebanho. As amostras de soro foram distribuídas em triplicata em tubos tipo Eppendorf estéreis, identificadas e mantidas estocadas a $-20^{\circ} \mathrm{C}$.

As amostras $(n=692)$ foram submetidas à técnica de RT-PCR para detectar presença do ácido nucleico viral e, consequentemente, infecção ativa pelo BVDV. Transcorrido o intervalo de quatro meses realizou-se a segunda colheita de sangue. Nessa ocasião, foram avaliados também pela RT-PCR os animais que apresentaram reação positiva na primeira colheita $(n=29)$, todos os animais que nasceram $(n=72)$ e também aqueles que apresentaram mortalidade embrionária e/ou fetal $(n=36)$ no intervalo compreendido entre a primeira e a segunda colheita de sangue.

De acordo com os resultados obtidos na RT-PCR a partir das amostras provenientes da segunda colheita foram realizadas colheitas adicionais de sangue, além de eutanásia e necropsia para a colheita de fragmentos de órgãos, em alguns animais pré-selecionados.

Extração do ácido nucleico (RNA). Para a extração do RNA, a partir do soro sanguíneo, as amostras foram descongeladas em banho-maria $37^{\circ} \mathrm{C}$ e alíquotas de $50 \mu \mathrm{L}$ foram processadas pelo método da sílica/isotiocianato de guanidina, conforme descrito por Boom et al. (1990). O RNA foi eluído em $30 \mu \mathrm{L}$ de água ultrapura estéril tratada com DEPC (Invitrogen ${ }^{\circledR}$ Life Techologies, EUA).

Para a extração do RNA a partir de tecidos, os fragmentos de órgãos foram triturados em PBS (tampão fosfato salina - pH 7,2) e a suspensão (10-20\% p/v) foi centrifugada por $15 \mathrm{~min}$ a $3000 \mathrm{xg}$ a $4^{\circ} \mathrm{C}$. Alíquotas de $250 \mu \mathrm{L}$ do sobrenadante foram incubadas com tampão de lise $(1 \%$ Nonidet P $40,2 \%$ SDS e $0,2 \mathrm{mg} / \mathrm{mL}$ proteinase $\mathrm{K}$ ) a $56^{\circ} \mathrm{C}$ por $30 \mathrm{~min}$. Posteriormente, o RNA foi extraído por meio de uma associação das técnicas de fenol/clorofórmio/álcool isoamílico e da sílica/isotiocianato de guanidina, descrita por Alfieri et al. (2006). O RNA foi eluído em $50 \mu \mathrm{L}$ de água ultrapura estéril tratada com DEPC (Invitrogen ${ }^{\circledR}$ Life Techologies, EUA).

Em todos os procedimentos de extração do RNA foram incluídas alíquotas de água ultrapura estéril como controle negativo e a cepa NADL do BVDV produzida em células MDBK (Madin Darby bovine kidney) como controle positivo.

Reação em cadeia da polimerase precedida de transcrição reversa - RT-PCR. As amostras biológicas foram avaliadas por RT-PCR utilizando os oligonucleotídeos iniciadores 103 senso (5'TAG CCA TGC CCT TAG TAG GAC 3' - nt 103-124) e 372 antissenso (5'ACT CCA TGT GCC ATG TAC AGC 3' - nt 372-392), selecionados a partir da sequência da região não-traduzida (5'UTR) do genoma viral do BVDV 1a, cepa NADL, que amplificam um produto com 290 pares de base (pb) (Weinstock et al. 2001). A técnica da RT-PCR foi realizada em amostras individuais de soro sanguíneo, de acordo com as modificações descritas por Pilz et al. (2005).

Alíquotas de $10 \mu \mathrm{L}$ dos produtos amplificados na PCR foram submetidas à eletroforese em gel de agarose $2 \%$ (Invitrogen ${ }^{\circledR}$ Life Techonologies, EUA) em tampão TBE pH 8,4 (89mM Tris; 89 mM ácido bórico; $2 \mathrm{mM}$ EDTA), sob voltagem constante (100V) por 60 min, corado com brometo de etídeo $(0,5 \mu \mathrm{g} / \mathrm{mL})$ e visualizado sob luz ultravioleta.

Sequenciamento. A especificidade de alguns produtos amplificados pela RT-PCR foi confirmada por sequenciamento. Os amplicons foram purificados utilizando os kits comerciais Illustra GFX PCR DNA e Gel Band Purification (GE Healthcare Life-Scien- ces, EUA) e sequenciados com o kit DYEnamic ET Dye Terminator (GE Healthcare Life-Sciences, EUA), em sequenciador automático ABI 3500 Genetic Analyzer (Applied Biosystems, Foster City, EUA), com os oligonucleotídeos senso e antissenso. A qualidade das sequências obtidas foi avaliada pelos programas Phred/ Phrap/Consed Analysis Program (http:/ /www.phrap.org/phredphrapconsed.html) e a identidade dos produtos foi comparada com as sequências depositadas em bases públicas de dados (GenBank, National Institute of Health, Bethesda, MD, EUA) utilizando o programa BLAST (http://www.ncbi.nlm.nih.gov/BLAST).

Vírus e células. A cepa citopática NADL do BVDV 1a foi amplificada em células MDBK cultivadas em meio Eagle-Dulbecco (Invitrogen ${ }^{\circledR}$ Life Techologies, EUA) suplementado com $7 \%$ de soro fetal bovino (SFB) livre de micoplasma, vírus e de anticorpos contra o BVDV (Invitrogen ${ }^{\circledR}$ Life Techologies, EUA), 55mg/ $\mu \mathrm{L}$ de gentamicina (Sigma Co., EUA) e 2,5mg/ $\mu \mathrm{L}$ de anfotericina B (Sigma Co., EUA). 0 monitoramento da contaminação das células e das partidas de SFB com BVDV NCP foi realizada por meio da RT-PCR (Pilz et al. 2005), utilizando os primers descritos por Weinstock et al. (2001). 0 título viral da suspensão celular foi calculado pelo método Reed \& Muench (1938).

Vírus-neutralização (VN). A detecção de anticorpos para o BVDV, nas amostras de soro provenientes dos animais reagentes positivos na RT-PCR e daqueles que apresentaram problemas reprodutivos no intervalo entre a primeira e segunda colheita de sangue, foi realizada por meio da técnica de vírus-neutralização (VN) realizada em microplacas de acordo com Pilz et al. (2005). Foram avaliadas diluições crescentes dos soros frente a doses

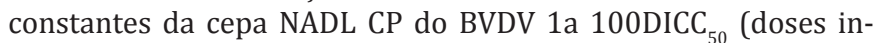
fectantes para $50 \%$ dos cultivos celulares) e diluições seriadas (base 2) do soro. Todas as análises foram realizadas em duplicata. 0 título de anticorpos foi expresso como a recíproca da diluição do soro que inibiu a replicação viral na monocamada celular induzido pela cepa viral padrão. Foram consideradas positivas as amostras que, após $72 \mathrm{~h}$ de incubação a $37^{\circ} \mathrm{C}$ em atmosfera de $5 \%$ de $\mathrm{CO}_{2}$, inibiram o ECP do BVDV a partir da diluição 1:8.

\section{RESULTADOS}

Das 692 amostras de soro provenientes da primeira colheita de sangue e avaliadas pela RT-PCR, em 29 (4,19\%) foi possível a amplificação de um produto com $290 \mathrm{pb}$. 0 Quadro 1 apresenta a distribuição das amostras positivas de acordo com a faixa etária dos animais avaliados. Das 29 amostras positivas, $26(89,65 \%)$ eram provenientes de vacas em produção e apenas três $(10,35 \%)$ de bezerras ou novilhas. Com relação à faixa etária foi observado aumento na frequência de animais com infecção ativa pelo BVDV de acordo com o aumento da faixa etária. A menor frequência $(0,63 \%)$ de reações positivas na RT-PCR foi observada na categoria de animais com até um ano de idade e a maior

Quadro 1. Distribuição etária dos animais positivos à RT-PCR para o vírus da diarreia viral bovina (BVDV)

\begin{tabular}{ccccc}
\hline Categoria & \multicolumn{2}{c}{ Idade/Meses } & \multicolumn{2}{c}{ Número de animais } \\
\cline { 3 - 5 } & & & Avaliados & Positivos (\%) \\
\hline 1 & 0 & 12 & 158 & $1(0,63)$ \\
2 & 12 & 24 & 151 & $2(1,32)$ \\
3 & 24 & 36 & 132 & $3(2,27)$ \\
4 & 36 & 48 & 95 & $3(3,16)$ \\
5 & 48 & 60 & 72 & $6(8,33)$ \\
6 & $\geq 60$ & 84 & $14(16,67)$ \\
Total & & 692 & $29(4,19)$
\end{tabular}


$(16,67 \%)$ em animais com idade superior a 5 anos. A distribuição dos animais em apenas duas categorias (fêmeas com idade $<60$ meses e $\geq 60$ meses) revelou que há 7,9 vezes mais chances (Epi Info 6.04) das fêmeas com idade $\geq$ 5 anos serem positivas para o BVDV do que as fêmeas mais jovens.

Na RT-PCR realizada a partir do material proveniente da segunda amostragem, dos 29 animais positivos na primeira avaliação, $2(6,9 \%)$ repetiram o resultado, o que possibilitou a caracterização desses dois animais como persistentemente infectados (PI). Os outros $27(93,1 \%)$ animais foram considerados transitoriamente infectados (TI). Considerando o rebanho total inicial de 692 animais o número de PI representou 0,29\% do rebanho.

Os dois animais PIs, foram denominados vacas 1 e 2 . Aproximadamente 30 dias após a identificação dos dois animais PI a vaca 1, com 37,2 meses, apresentou quadro clínico agudo de diarreia, de cor escura, com presença de sangue e dificuldade respiratória. A morte do animal ocorreu no período de 48 a 72 h após o início dos sinais clínicos. Apesar da impossibilidade da realização de exames laboratoriais adicionais em material proveniente desse animal, o quadro clínico sugere que a mesma tenha desenvolvido DM.

A vaca 2 era lactante, foi isolada do rebanho e permaneceu positiva para o BVDV por mais duas reações de RT-PCR realizadas no intervalo total de 12 meses. Posteriormente, esse animal foi eutanasiado, necropsiado e fragmentos de órgãos (baço, fígado, linfonodos mediastínicos e mesentéricos, pulmão e rins) também resultaram positivos na RT-PCR. Por ocasião da eutanásia essa vaca estava gestante de gêmeos, pois havia sido inseminada antes da confirmação de animal PI. Os fragmentos dos órgãos dos dois fetos (baço, fígado, pulmão e rins) também resultaram positivos para o BVDV na RT-PCR.

No período entre a primeira e a segunda colheita 72 bezerras nasceram no rebanho sendo que 1 (1,39\%) apresentou resultado positivo na RT-PCR. Essa bezerra, que era filha da vaca PI 2, foi repetidamente avaliada por RT-PCR e apresentou resultado positivo em três ocasiões consecutivas. Essa fêmea, mantida separada do rebanho foi submetida à eutanásia aos 12 meses de idade e a análise dos fragmentos de órgãos (baço, fígado, glândulas salivares, linfonodos mediastínicos e mesentéricos, ovários, pulmão e rins) também resultou positiva na RT-PCR.

Nenhuma das 36 amostras de soros, provenientes de animais que apresentaram problema reprodutivo no intervalo entre a primeira e a segunda colheita, apresentou reação positiva na RT-PCR.

A reação de sequenciamento, realizada nos produtos amplificados pela PCR provenientes das vacas 1 e 2 e da bezerra PI, além de três outras vacas TI selecionadas aleatoriamente, confirmou a especificidade dos amplicons que apresentaram identidade com o BVDV 1.

Dos 27 animais TI, 23 (85,19\%) eram soropositivos (título $\geq 8$ ) para o BVDV nas amostras provenientes da primeira colheita. Dos quatro $(14,82 \%)$ animais negativos, três $(75 \%)$ apresentaram soroconversão com títulos $\geq 8$ nas amostras de soro provenientes da segunda colheita (Quadro 2).
Quadro 2. Títulos de anticorpos neutralizantes para o vírus da diarreia viral bovina (BVDV) no soro de 27 animais transitoriamente infectados pelo BVDV, identificados em dois períodos distintos com intervalo de quatro meses

\begin{tabular}{ccc}
\hline Intervalo de títulos $\mathrm{VN}^{*}$ & \multicolumn{2}{c}{ Número de animais } \\
\cline { 2 - 3 } & Primeira colheita & Segunda colheita \\
\hline 2 a 4 & 4 & 1 \\
8 a 16 & 10 & 11 \\
32 a 1024 & 13 & 15 \\
* VN = vírus-neutralização. & &
\end{tabular}

Quadro 3. Títulos de anticorpos neutralizantes para o vírus da diarreia viral bovina no soro de $\mathbf{3 6}$ animais com distúrbios reprodutivos, identificados em dois períodos distintos com intervalo de quatro meses

\begin{tabular}{ccc}
\hline Intervalo de títulos VN* & \multicolumn{2}{c}{ Número de animais } \\
\cline { 2 - 3 } & Primeira colheita & Segunda colheita \\
\hline 2 a 4 & 21 & 9 \\
8 a 16 & 11 & 6 \\
32 a 2048 & 4 & 21
\end{tabular}

*VN = vírus-neutralização.

Quadro 4. Títulos de anticorpos neutralizantes para o vírus da diarreia viral bovina no soro de 3 animais persistentemente infectados, identificados em quatro períodos distintos com intervalo de 18 meses

\begin{tabular}{ccccc}
\hline Animal & \multicolumn{4}{c}{ Título VN* } \\
\cline { 2 - 5 } & $\begin{array}{c}\text { Primeira } \\
\text { colheita }\end{array}$ & $\begin{array}{c}\text { Segunda } \\
\text { colheita }\end{array}$ & $\begin{array}{c}\text { Terceira } \\
\text { colheita }\end{array}$ & $\begin{array}{c}\text { Quarta } \\
\text { colheita }\end{array}$ \\
\hline Vaca 1 & 64 & 32 & $\mathrm{NR}^{\mathrm{a}}$ & $\mathrm{NR}^{\mathrm{a}}$ \\
Vaca 2 & $\leq 4$ & $\leq 4$ & $\leq 4$ & $\leq 4$ \\
Bezerra & $\leq 4$ & $\leq 4$ & 8 & 16
\end{tabular}

$\bar{*}$ VN = vírus-neutralização, ${ }^{a} \mathrm{NR}=$ não realizada.

A VN realizada no soro das 36 fêmeas que apresentaram distúrbio reprodutivo no período compreendido entre a primeira e a segunda colheita de sangue, resultou, inicialmente, em 21 (58,33\%) amostras negativas para o BVDV. Na segunda colheita apenas nove $(25 \%)$ amostras permaneceram negativas e 27 (75\%) mostraram títulos $\geq 8$ (Quadro 3).

Dos três animais PI acompanhados durante o estudo, a vaca 1 , que provavelmente morreu de DM, apresentou títulos de anticorpos considerados positivos (64 e 32) nas duas avaliações realizadas no intervalo de 6 meses. A vaca 2 apresentou resultado negativo (título: $\leq 4$ ) na VN em todas as quatro avaliações realizadas no período de 18 meses. A bezerra PI foi soronegativa (título: $\leq 4$ ) nas duas avaliações iniciais; fracamente positiva (título: 8) na terceira avaliação; e positiva (título: 16) na quarta avaliação que antecedeu a eutanásia (Quadro 4).

\section{DISCUSSÃO}

A maior frequência de animais adultos positivos por RT-PCR para o BVDV pode, em parte, ser explicada pelo tipo de manejo diferenciado a que eram submetidas as várias categorias de animais do rebanho. Do nascimento ao período que antecede o primeiro parto das novilhas, os animais jovens não tinham contato com animais adultos. 
Portanto, no rebanho avaliado, evidenciou-se que o manejo zootécnico adotado contribuiu para que a circulação do BVDV ficasse muito mais concentrada na categoria de animais adultos.

0 resultado da primeira avaliação do perfil da infecção pelo BVDV evidenciou ainda a presença de atividade viral mesmo em um rebanho em que todos os animais da categoria de reprodução eram regularmente vacinados, em intervalos semestrais, contra o BVDV. Outro aspecto a ser destacado ainda nessa avaliação, é que a identificação do BVDV foi mais frequente justamente naquelas categorias de animais que, pela faixa etária, haviam recebido o maior número de doses de vacina. 0 delineamento deste estudo não permitiu explicar esse achado. Uma resposta conclusiva somente pode ser obtida por meio de estudos que avaliem o potencial de resposta imune humoral e celular de animais mais velhos frente às outras categorias constituintes de um rebanho bovino leiteiro de alta produção e com manejo intensivo.

Dos 29 animais positivos para o BVDV 1 pela RT-PCR na primeira avaliação, dois $(6,9 \%)$ repetiram o resultado na segunda análise. Com isso, 27 animais foram classificados como TI e dois como PI (Larson et al. 2005). Considerando o número total de animais do rebanho $(n=692)$ os percentuais de animais TI e PI foram de 3,9\% e 0,29\%, respectivamente. A análise comparativa da frequência média de animais TI em rebanhos bovinos leiteiros de alta produção submetidos a manejo intensivo é difícil de ser realizada, uma vez que essa informação não é disponível na literatura. Porém, a prevalência de animais PI pode variar de 0,5 a 2\% (Houe 1999). Em bezerros leiteiros Fulton et al. (2006) descreveram prevalência de $0,4 \%$ de PI. No presente estudo, na primeira colheita, nenhum animal jovem foi positivo para o BVDV. Os dois animais PI identificados pertenciam à categoria de vacas lactantes, sendo uma com 37,2 e outra com 50,3 meses de idade. 0 baixo percentual de animais PI pode ser justificado por dois motivos. Primeiro, o manejo do rebanho não incluía a criação de animais machos. Os bezerros eram descartados logo após o nascimento e com esse manejo a probabilidade de animais PI é reduzida em 50\%. Segundo, as duas vacas PI não eram originadas do próprio rebanho. Elas haviam sido adquiridas de terceiros, pois o rebanho, ainda em expansão, com frequência incorporava animais de outras procedências sendo, por isso, considerado um rebanho aberto.

A vaca 1 morreu sem que se tivesse colhido material para a realização de exames que permitissem esclarecer a causa da morte. Porém, os sinais clínicos relatados sugerem que esse animal desenvolveu DM.

A vaca 2 , com 50,3 meses de idade, pariu uma bezerra que, posteriormente, também foi confirmada como PI. A bezerra foi submetida a quatro colheitas de sangue com intervalos de pelo menos oito semanas entre elas. Amostras de soro de todas as colheitas demonstram pela RT-PCR a presença do BVDV. A bezerra PI foi acompanhada até, aproximadamente, os 12 meses de idade. Nesse período o animal não apresentou qualquer evidência de imunodepressão com infecções intercorrentes. 0 desenvolvimento corporal (peso x altura) da bezerra PI também foi igual à média do rebanho. À necropsia, realizada aos 12 meses, todos os órgãos analisados pela RT-PCR demonstraram a presença do BVDV. Todos os órgãos obtidos na necropsia da vaca 2 e analisados pela RT-PCR também resultaram positivos para o BVDV. No momento da eutanásia esse animal apresentava gestação gemelar e os dois fetos também estavam infectados pelo BVDV, ratificando a transmissão vertical do vírus (Lindberg \& Houe 2005).

Com relação à pesquisa de anticorpos para o BVDV por meio da técnica $V N$ realizada nosoro dos animais identificados como PI, foram obtidos resultados distintos. A vaca 2 foi negativa para a presença de anticorpos anti-BVDV nas quatro amostras de soro avaliadas no intervalo de 18 meses. Esse resultado está de acordo com a literatura que relata que, animais PI são imunotolerantes ao BVDV e,com frequência, são soronegativos (Ridpath \& Flores 2007). A bezerra PI apresentou títulos negativos nas amostras das duas primeiras colheitas e títulos positivos nas amostras de soro provenientes da terceira e quarta colheitas. Deve-se ressaltar que esse resultado foi repetido na mesma amostra de soro por três ocasiões consecutivas. A vaca 1 , que provavelmente morreu de DM, apresentou título positivo de anticorpos para o BVDV nas amostras de soro provenientes das duas colheitas. Embora sejam imunotolerantes à cepa dea BVDV que induziu a tolerância, os animais PI são imunocompetentes a outros antígenos (Brock 1995) e podem também desenvolver resposta imunológica contra cepas heterólogas do BVDV (Baker 1995).

Esses resultados sorológicos demonstram que a prática de rastreamento de animais PI em rebanhos apenas por meio de exames sorológicos pode falhar na identificação do PI. No presente estudo, utilizando essa prática, na dependência da época da colheita de soro, dois dos três animais PI identificados pela RT-PCR poderiam ter sido mantidos no rebanho, pois eram soropositivos.

A circulação viral no rebanho foi também identificada por meio da sorologia pareada dos animais TI que resultou em soroconversão, com aumento de dois ou mais $\log _{2}$ no título de anticorpos, em 10 (37,04\%) animais. O BVDV foi identificado pela RT-PCR no soro de animais, caracterizando viremia, mesmo no soro de vacas $(n=13 ; 48,15 \%)$ com títulos de anticorpos $\geq 32$. Este achado sugere que, em algumas situações, os anticorpos neutralizantes podem não ser suficientes para prevenir a viremia pelo BVDV.

Por ocasião da primeira colheita de soro, a maioria dos animais TI $(62,96 \%)$ possuia alto título de anticorpos ou não era gestante. Com isso, o impacto específico da infecção na esfera reprodutiva desse grupo de animais não foi grande. Nas fêmeas TI gestantes foram observados: uma reabsorção embrionária, um natimorto e o nascimento de 14 bezerros sendo 10 machos e 4 fêmeas. Os machos nativivos foram descartados logo após o parto e apenas uma fêmea permaneceu no rebanho cujo resultado na RT-PCR foi negativo para o BVDV. As outras três bezerras geradas pelas vacas TI morreram, sendo duas por diarreia com menos de um mês de idade e outra por clostridiose aos 4 meses de idade. Esses animais, por terem morrido anteriormente à segunda colheita de soro não foram avaliados pela RT-PCR e, com isso, não foi possível determinar se eram PI. 
Durante o período de quatro meses de intervalo entre a primeira e a segunda colheita de soro dos 36 animais com problemas de reprodução não foi possível caracterizá-los como TI, ou seja, foram negativos na RT-PCR para a detecção do BVDV no soro sanguíneo. Destes, na primeira avaliação, $21(58,33 \%)$ animais foram negativos na VN para a pesquisa de anticorpos anti-BVDV e $15(41,67)$ foram positivos. A sorologia pareada realizada no soro desses animais revelou soroconversão em 12 (33,33\%) animais e 20 (55,56\%) animais apresentaram aumento médio de $3 \log _{2}$ (máximo de $8 \log _{2}$ ) nos títulos finais. Ainda nesse grupo de animais o percentual de soronegativos reduziu para $25 \%$. A alta taxa de soroconversão e a redução na proporção de animais soronegativos observada nesses animais sugerem infecção pelo BVDV. Essa hipótese é reforçada pela constatação de que o vírus, no período da avaliação, foi identificado pela RT-PCR na categoria de animais lactantes que eram submetidos ao manejo diário em ambientes comuns. Como o BVDV pode ocasionar mortalidade embrionária (Grooms 2006), a somatória desses resultados pode sugerir a participação do BVDV na gênese dos problemas reprodutivos observados, mesmo considerando o fato de que todos os 36 animais haviam recebido, no mínimo, duas doses de vacina inativada para a profilaxia dessa virose. Falhas vacinais em relação à BVD são frequentemente descritas na literatura e podem ser decorrentes da grande variabilidade antigênica entre as cepas virais circulantes, entre outros fatores (Flores et al. 2000, Bolin \& Grooms 2004).

A BVD é uma doença com múltiplas formas de apresentação que podem variar desde infecções subclínicas e inaparentes, DM, doença hemorrágica, infecção entérica e problemas reprodutivos (Goyal 2005, Liebler-Tenorio 2005). Vários sinais clínicos observados na infecção pelo BVDV podem também ser comuns a outras doenças ocasionadas por vírus, bactérias, protozoários, micotoxicoses (Grooms 2006) e, até mesmo, por falhas nos manejos zootécnico e nutricional. Apesar de existirem no mercado nacional vacinas com vírus inativado para a profilaxia da infecção, a presença de diferentes tipos, genotipos e variantes antigênicas em cepas de BVDV circulantes pode ser responsável por falhas vacinais, particularmente aquelas relacionadas às falhas na proteção fetal (Flores et al. 2000).

Dentre as observações de campo e laboratoriais destacam-se: i) a caracterização do rebanho como aberto; ii) a alta taxa de mortalidade embrionária; iii) a presença de animais TI e PI; iv) a alta taxa de soroconversão identificada em animais com mortalidade embrionária; sugerem a participação do BVDV na etiologia da baixa eficiência reprodutiva do rebanho avaliado.

No presente estudo alguns resultados, e mesmo observações clínicas, destacam-se pela baixa frequência com que são relatados na literatura em casos de BVD tais como: i) grande circulação viral, caracterizada pela presença de animais TI, mesmo em um rebanho periodicamente vacinado; ii) grande variação (títulos) no perfil sorológico dos animais vacinados; iii) presença de animais PI soropositivos para o BVDV; iv) ausência de algumas características da infecção pelo BVDV como o nascimento de animais com defeitos congênitos ou de bezerros com peso corporal abaixo da média da raça e a não ocorrência de mumificação fetal.
Por outro lado, a infecção ativa no rebanho pode ter sido originada por variantes antigênicas do BVDV distintas da cepa vacinal. Com isso, os resultados do presente estudo reforçam a importância e a complexidade das infecções pelo BVDV. Evidencia-se ainda a dificuldade de controle e profilaxia dessa importante virose em rebanhos bovinos leiteiros de alta produção sob manejo intensivo. Considerando a diversidade das cepas de BVDV circulantes nos rebanhos bovinos brasileiros são necessários, no campo da vacinologia, estudos que incluam a análise comparativa da proteção contra viremia e, consequentemente, proteção fetal em animais vacinados com imunógenos constituídos por cepas padrão do BVDV em relação aos vacinados com cepas autóctones.

Agradecimento.- Este trabalho foi financiado com recursos obtidos junto às agências de fomento à pesquisa CNPq, CAPES, FINEP e Fundação Araucária (FAP/PR). A.A. Alfieri e A.F. Alfieri são bolsistas de produtividade em pesquisa do CNPq.

\section{REFERÊNCIAS}

Alfieri A.A., Parazzi M.E., Takiuchi E., Médici K.C. \& Alfieri A.F. 2006. Frequency of group A rotavirus in diarrhoeic calves in Brazilian cattle herds, 1998-2002. Trop. Anim. Hlth Prod. 38:521-526.

Baker J.C. 1995. The clinical manifestations of bovine viral diarrhea infection. Vet. Clin. North Am., Food Anim. Pract. 11:425-446.

Becher P., Avalos Ramirez R., Orlich M., Cedillo Rosales S., König M., Schweizer M., Stalder H., Schirrmeier H., Thiel H.J. 2003. Genetic and antigenic characterization of novel pestivirus genotypes: implications for classification. Virology. 311(1):96-104.

Bolin S.R. \& Grooms D.L. 2004. Origination and consequences of bovine viral diarrhea virus diversity. Vet. Clin. North Am., Food Anim. Pract. 20:51-68.

Bolin S.R., Lim A., Grotelueschen D.M., Mcbeth W.W., Cortese V.S. 2009. Genetic characterization of bovine viral diarrhea viruses isolated from persistently infected calves born to dams vaccinated against bovine viral diarrhea virus before breeding. Am. J. Vet. Res. 70(1):86-91.

Boom R., Sol C.J.A., Salimans M.M.M., Jansen C.L., Wertheim-van Dillen P.M.E. \& Van der Noordaa J. 1990. Rapid and simple method for purification of nucleic acids. J. Clin. Microbiol. 28:495-503.

Brock K.V. 1995. Diagnosis of bovine viral diarrhea virus infections. Vet. Clin. North Am., Food Anim. Pract. 11:549-561.

Brock K.V., Grooms D.L. \& Givens M.D. 2005. Reproductive disease and persistent infections, p.145-156. In: Goyal S.M. \& Ridpath J.F. (Eds), Bovine Viral Diarrhea Virus. Wiley-Blackwell, Iowa.

Cortez A., Heinemann M.B., de Castro A.M.M.G., Soares R.M., Pinto A.M.V., Alfieri A.A., Flores E.F., Leite R.C. \& Richtzenhain L.J. 2006. Genetic characterization of Brazilian bovine viral diarrhea virus isolate by partial nucleotide sequencing of the $5^{\prime}$ UTR region. Pesq. Vet. Bras. 26:211216.

Flores E.F., Weiblen R., Gil L.H.V.G., Tobias F.L., Lima M., Garcez D.C. \& Botton S.A. 2000. Diversidade antigênica de amostras do vírus da diarreia viral bovina isoladas no Brasil: implicações para o diagnóstico e estratégias de imunização. Arq. Bras. Med. Vet. Zootec. 52:11-17.

Flores E.F., Ridpath J.F., Weiblen R., Vogel F.S.F. \& Gil L.H.V.G. 2002. Phylogenetic analysis of Brazilian bovine viral diarrhea virus type 2 (BVDV-2) isolates: evidence for a subgenotype within BVDV-2. Virus Res. 87:5160

Flores E.F., Weiblen R., Vogel F.S.F., Roehe P.M., Alfieri A.A. \& Pituco E.M. 2005. A infecção pelo vírus da diarreia viral bovina (BVDV) no Brasil - histórico, situação atual e perspectivas. Pesq. Vet. Bras. 25:125-134.

Fulton R.W. \& Burge L.J. 2000. Bovine viral diarrhea types 1 and 2 antibody response in calves receiving modified live virus or inactived vaccines. Vaccine 19:264-274. 
Fulton R.W., Hessman B., Johnson B.J., Ridpath J.F., Saliki J.T., Burge L.J., Sjeklocha D., Confer A.W., Funk R.A. \& Payton M.E. 2006. Evaluation of diagnostic tests used for detection of bovine viral diarrhea virus and prevalence of subtypes $1 \mathrm{a}, 1 \mathrm{~b}$, and $2 \mathrm{a}$ in persistently infected cattle entering a feedlot. J. Am. Vet. Med. Assoc. 228:578-584.

Goyal S.M. 2005. Diagnosis, p.197-208. In: Goyal S.M. \& Ridpath J.F. (Eds), Bovine Viral Diarrhea Virus. Wiley-Blackwell, Iowa.

Grooms D.L. 2006. Reproductive losses caused by bovine viral diarrhea virus and leptospirosis. Theriogenology 66:624-628.

Houe H. 1999. Epidemiological features and economical importance of bovine virus diarrhea virus (BVDV) infections. Vet. Microbiol. 64:89-107.

Kadir Y., Förster C., Bank-Wolk B., Yilmaz Z., Alken F., Ozkul A., Burgu I., Rosales S.C., Thiel H. \& Köning M. 2008. Genetic heterogeneity of bovine viral diarrhea virus (BVDV) isolates from Turkey: Identification of a new subgroup in BVDV-1. Vet. Microbiol. 130:258-267.

Kennedy J.A. 2006. Diagnostic efficacy of a reverse transcriptase-polymerase chain reaction assay to screen cattle for persistent bovine viral diarrhea virus infection. J. Am. Vet. Med. Assoc. 229:1.472-1.474.

Kirkland P.D., Frost M.J., Finlaison D.S., King K.R., Ridpath J.F. \& Gu X. 2007. Identification of a novel virus in pigs - Bungowannah virus: A possible new species of pestivirus. Virus Res. 129:26-34.

Larson R.L., Miller R.B., Kleiboeker S.B., Miller M.A. \& White B.J. 2005. Economic costs associated with two testing strategies for screening feeder calves for persistent infection with bovine viral diarrhea virus. J. Am. Vet. Med. Assoc. 226:249-254.

Liebler-Tenorio E.M. 2005. Pathogenesis, p.121-143. In: Goyal S.M. \& Ridpath J.F. (Eds), Bovine Viral Diarrhea Virus. Wiley-Blackwell, Iowa.

Lindberg A. \& Houe H. 2005. Characteristics in the epidemiology of bovine viral diarrhea virus (BVDV) of relevance control. Prev. Vet. Med. 72(1/2):55-73.
Lunardi M., Headley S.A., Lisbôa J.A.N., Amude A.M. \& Alfieri A.A. 2008. Outbreak of acute bovine viral diarrhea in Brazilian beef cattle: Clinicopathological findings and molecular characterization of a wild-type BVDV strain subtype 1b. Res. Vet. Sci. 85:599-604.

Nagai M., Hayashi M., Itou M., Fukutomi T., Akashi H., Kida H. \& Sakoda Y. 2008. Identification of new genetic subtypes of bovine viral diarrhea virus genotype 1 isolated in Japan. Virus Genes 36:135-139.

Pilz D., Alfieri A.F. \& Alfieri A.A. 2005. Comparison of different protocols for the bovine viral diarrhea virus detection by RT-PCR in pools of whole blood and blood serum artificially contaminated. Semina, Ciênc. Agrárias 26:219-228.

Quincozes C.G., Fischer G., Hübner S.O., Vargas G.D., Vidor T. \& Brod C.S. 2007. Prevalência e fatores associados à infecção pelo vírus da diarréia viral bovina na região Sul do Rio Grande do Sul. Semina, Ciênc. Agrárias 28:269-276

Reed L.J. \& Muench H. 1938. A simple method of estimating 50 per cent end point. Am. J. Hygiene 27:493-497.

Ridpath J.F. \& Flores E.F. 2007. Flaviviridae, p.565-591. In: Flores E.F. (Ed.), Virologia Veterinária. Editora da Universidade Federal de Santa Maria, Santa Maria, RS.

Schirrmeier H., Strebelow G., Depner K., Hoffmann B., Beer M. 2004. Genetic and antigenic characterization of an atypical pestivirus isolate, a putative member of a novel pestivirus species. J. Gen. Virol. 85:36473652.

Vilcek S., Ridpath J.F., Van Campen H., Cavender J.L. \& Warg J. 2005. Characterization of a novel pestivirus originating from a pronghorn antelope. Virus Res. 108:187-193.

Weinstock D., Bhudevi B. \& Anthony E.C. 2001. Single-tube single-reverse transcriptase PCR assay for detection of bovine viral diarrhea virus in pooled bovine serum. J. Clin. Microbiol. 39:343-346. 